\title{
Resursele materiale și virtuale utilizate în terapia tulburărilor de limbaj. Studiu descriptiv bazat pe focus-grup
}

\author{
Carolina BODEA HAȚEGAN ${ }^{1}$, Dorina TALAȘ², Raluca TRIFU³
}

\begin{abstract}
This article describes a research study developed during the webinar organized in order to celebrate 6 th of March as European Day of Speech \& Language Therapy. In this research participated Romanian SLTS $(N=150)$. The research was based on the following objectives: to identify the typology of the present used resources in the Romanian SLT field; to implement the Padlet as a tool for collecting and sharing data and to identify the area of resources that has to be developed. Results demonstrated that SLTs mainly use virtual resources $(V R=106)$ in their present work and that material resources that can be used online is the less detailed and mentioned category (MRV=17). The third category of resources is the category of material resources (MR), those that are to be used mainly during face-to-face SLT therapy. This category is represented by a relatively low number of units, compared with VR $(M R=61)$. Regarding the use of Padlet, we consider that this focused-group based research was enhanced with success, participants in the research, even if they were a numerous group, and the research was developed online, had the chance to express their points of view, without difficulties.
\end{abstract} \section{Introducere}

Keywords: Padlet, focus-group, SLT, resources, virtual resources, material resources

Actualizare constantă a resurselor necesare evaluării și intervenției în domeniul terapiei tulburărilor de limbaj și comunicare constituie o preocupare intrinsecă a specialiștilor care activează în acest domeniu, dar și a profesioniștilor din domenii conexe. Preocuparea pentru accesul unui număr cât mai larg de beneficiari către serviciile de logopedie sau terapia tulburărilor de limbaj prin oferirea de terapii în mediul online este o preocupare mai veche, cu studii începute încă din anii 2000 (Edwards et al., 2012; Harrison, 2011; Polovoy, 2008).Pentru o perioadă implicațiile au fost destul de reduse și uzul lor era marcat mai mult de specificul local sau a unui areal geografic, fără o distribuție consistentă în domeniu, deși posibilele beneficii erau discutate (Cohn, 2012; Theodoros, 2011; Todd Houston et al., 2012). Un studiu realizat de grupul de lucru WP- Telepractice în
SLT, din cadrul CPLOL (Trifu et al., 2018) a indicat faptul că telepractica este folosită într-o mică parte în spațiul european și că un un număr mic de participanți la studiu declarau că folosesc în mod personal telepractica. Dar manifestau interes pentru a folosi această modalitate de adresare a beneficiarilor în viitor. Mai mult acest serviciu era decontat doar într-o mică măsură de sistemul de sănătate. În ceea ce privea tipul de tehnologii sau de platforme utilizate, skype-ul este utilizat pe scară largă pentru sesiunile de telepractică, urmat de programe speciale pentru telepractică în procent de 5,04\% . Copiii și adulții beneficiază în mod egal de sesiuni de telepractică, care sunt utilizate cu pacienții (25\%) sau cu aparținătorii (11\%). Iar $43 \%$ participanții consideră că intervenția prin telepractică poate fi la fel de eficientă ca și sesiunile față în față. Rezultatele studiului (Trifu et al., 2018) insistau asupra posibilităților largi pe 
care apelul la tehnologiile informației le poate avea în oferirea de servicii specializate în terapia tulburărilor de limbaj și de comunicare și întrevedeau posibilele schimbări care s-ar putea produce în domeniul SLT, dar observa și reticența pe care terapeuții de limbaj o aveau față de uzul noilor tehnologii și posibilele dificultăți de ordin juridic, cele de reglementare a procedurilor sau de asigurarea securității, confidențialității și a datelor în mediul online. Concluzia grupului de lucru era că terapia online în SLT / SLP este benefică în caz de distanța sau acces redus la specialiștii în anumite domenii, dar provocările sunt mari, iar formarea și resursele speciale sunt necesare pentru ședințele de terapie.

Anul 2020 a adus schimbări marcante în acest domeniu, modificări pe care studiile anterioare asupra terapiei limbajului și educației online nu le puteau prevede sau nu le puteau aștepta atât de rapid. Modificările au fost posibile de activarea a două evenimente marcante: pe de o parte se impune a fi adusă în discuție pandemia Covid - 19 determinată de virusul SARS-Cov2 și declararea stării de urgență și de alertă la nivel mondial, iar pe de altă parte,

Tabel 1 - Distribuția estimativă a accesului la internet în 2021. Conform https://www.internetworldstats.com/

\begin{tabular}{|c|c|c|c|c|c|c|}
\hline Continente & $\begin{array}{l}\text { Populație } \\
\text { (Estimare } \\
\text { 2021) }\end{array}$ & $\begin{array}{l}\text { Populația } \\
\text { lumii \% }\end{array}$ & $\begin{array}{l}\text { Utilizatori } \\
\text { internet } 31 \\
\text { Dec } 2020\end{array}$ & $\begin{array}{l}\text { Procent în } \\
\text { populație } \\
\text { (\% Pop.) }\end{array}$ & $\begin{array}{l}\text { Creșterea } \\
\text { în } \\
\text { intervalul } \\
\text { 2000-2021 }\end{array}$ & $\begin{array}{l}\text { Distribuți } \\
\text { a } \\
\text { accesului } \\
\text { la internet } \\
\text { la nivel } \\
\text { mondial } \\
\%\end{array}$ \\
\hline Africa & $1,373,486,514$ & $17.4 \%$ & $634,863,323$ & $46.2 \%$ & $13,963 \%$ & $12.5 \%$ \\
\hline Asia & $4,327,333,821$ & $54.9 \%$ & $2,707,088,121$ & $62.6 \%$ & $2,268 \%$ & $53.1 \%$ \\
\hline Europa & $835,817,917$ & $10.6 \%$ & $728,332,705$ & $87.1 \%$ & $593 \%$ & $14.3 \%$ \\
\hline
\end{tabular}

dinamica creșterii exponențiale a accesului la serviciile digitale și de internet. Statistica uzului accesului la internet la nivelul anului 2021, față de 2020, indică o creștere substanțială a accesului și utilizării internetului, pentru unele regiuni, cum este spațiul European, observându-se o creștere procentuală și de 593\%, un procent greu de imaginat în anii precedenți. Conform datelor statistice (Europe Internet Use and Population Statistics, 2020; WIS, 2020) în anul 2011 exista un număr de 2,1 miliarde de utilizatori de internet la nivel mondial și aproximativ $58 \%$ au raportat că au făcut căutări legate de informarea și accesul la servicii medicale și auxiliar medicale. În 2020, numărul utilizatorilor de internet a crescut și nevoia de ajutor prin intermediul internetului a crescut în mod proporțional, substanțial. Din punct de vedere statistic accesul la internet va facilita implicit și accesul către profesioniștii și specialiștii din domeniul terapiei tulburărilor de limbaj, prin apel la serviciile de terapie online. Conform estimărilor actuale (WIS, 2020), situația accesului la internet, distribuit pe regiuni geografice se configurează conform datelor prezentate în tabelul numărul 1.

\section{a}




\begin{tabular}{|c|c|c|c|c|c|c|}
\hline $\begin{array}{l}\text { America } \\
\text { latină / } \\
\text { Caraibe }\end{array}$ & $659,743,522$ & $8.4 \%$ & $477,848,538$ & $72.4 \%$ & $2,544 \%$ & $9.4 \%$ \\
\hline $\begin{array}{l}\text { Orientul } \\
\text { Mijlociu }\end{array}$ & $265,587,661$ & $3.4 \%$ & $188,132,198$ & $70.8 \%$ & $5,627 \%$ & $3.7 \%$ \\
\hline $\begin{array}{l}\text { America de } \\
\text { Nord }\end{array}$ & $370,322,393$ & $4.7 \%$ & $332,912,495$ & $89.9 \%$ & $208 \%$ & $6.5 \%$ \\
\hline $\begin{array}{l}\text { Oceania / } \\
\text { Australia }\end{array}$ & $43,473,756$ & $0.6 \%$ & $29,286,392$ & $67.4 \%$ & $284 \%$ & $0.6 \%$ \\
\hline $\begin{array}{l}\text { Număr } \\
\text { total la } \\
\text { nivel } \\
\text { mondial } \\
\end{array}$ & $7,875,765,584$ & $100.0 \%$ & $5,098,463,772$ & $64.7 \%$ & $1,312 \%$ & $100.0 \%$ \\
\hline
\end{tabular}

Adresabilitatea în terapia și educația online în anul 2020 a fost diversă, iar diagnostice care erau considerate a fi imposibil de adresat prin terapie online, au constituit în final provocări care și-au găsit rezolvarea. Într-un studiu (Alqudah et al., 2021) care viza impactul Covid- 19 asupra persoanelor protezate auditiv se atrăgea atenția asupra dificultății de apelare, în varianta clasică, a terapeuților de limbaj și implicit nevoia de utilizare a unor modalități alternative de acces a serviciilor logopedice. Un alt studiu (Becker \& Gillespie, 2021) semnaliza beneficiile și limitările telepracticii atunci când adresabilitatea este în tulburările de voce. Alți autori (Pamplona \& Ysunza, 2020) s-au concentrat pe dificultățile apărute în telepractica logopedică în condițiile diagnosticului de despicătură palatină, dar și a implicațiilor telepracticii în recuperarea afaziei (Finch et al., 2020; Hall et al., 2013). Dificultatea majoră menționată în literatura a fost cea care a presupus oferirea de terapii on line în condițiile unui diagnostic de tulburare de spectru autist (Narzisi, 2020; Samadi et al., 2020), deși demersuri pentru facilitarea accesului la resurse logopedice prin terapia online, mai ales în contextul limitărilor impuse de spațiul geografic au fost demarate încă din 2010 (Boisvert et al., 2010; Parsons et al., 2017).

O relevanță aparte se pare a avea un alt studiu (Lam et al., 2021) care s-a concentrat pe percepția serviciilor de terapie logopedică online, prin prisma aprecierilor venite din partea părinților și a elevilor beneficiari. Studiul indica faptul că, deși eficacitatea terapiilor logopedice online a fost extrem de apreciată de către părinți ( $95 \%$ CI 3,303,66) și elevi (95\% CI 3,21-3,76), ambele grupuri credeau că terapia logopedică online era mai puțin eficientă decât terapia față în față (părinți: 95\% CI 2,142,52; elevi: $95 \%$ CI 2,08-2,65). Mai mult, părinții au preferat practicile la fața locului decât terapia online $(95 \%$ 2,042,43 ), în timp ce elevii nu au preferat un mod de practică față de celălalt $(95 \%$ 2,74-3,41). O asociere semnificativă între eficacitatea terapiei online și o preferință pentru serviciile de terapie online de a fost găsită numai în rândul elevilor ( $\tau=$ .43, $\mathrm{P}<$ <.001), nu în rândul părinților ( $\tau=$ .07; $\mathrm{P}=.44$ ). Studiul (Lam et al., 2021) sublinia faptul că deși terapia logopedică 
on-line este o alternativă acceptabilă de furnizare a serviciilor logopedice, terapeuții și părinții trebuie să joace un rol mai proactiv în serviciile de terapie online pentru a facilita comunicarea eficientă între profesioniști și beneficiari. În mod similar, un alt studiu (Fong et al., 2021) atrăgea atenția asupra dificultăților iscate de adaptare rapidă la oferirea de servicii terapeutice online, comparativ cu situația în care există deja o experiență în acest sens.

Percepția specialiștilor asupra oferirii de servicii de terapie online este la fel de importantă. Spre exemplu terapeuții din Croația (Kraljević et al., 2020), majoritatea angajați în practica clinică și privată au oferit servici de terapie logopedică online, dar s-au confruntat și cu refuzul beneficiarilor, refuz marcat de lipsa echipamentului, insuficienta independență și neîncrederea în eficacitatea telepracticii. Deși doar 3\% dintre SLP-uri au dobândit unele cunoștințe formale de telepractică înainte de pandemie, peste $70 \%$ și-au exprimat satisfacția față de terapia online, deoarece le-a permis să ofere servicii clinice în condiții excepționale. Într-o altă parte a lumii, într-un studiu similar (Kim et al., 2020) care viza percepția specialiștilor în terapia tulburărilor de limbaj asupra terapiei online, s-a evidențiat faptul că majoritatea terapeuților erau dispuși să participe la programe de educație, dar că doar o mică parte au utilizat aceste tehnologii înainte de pandemie. Scepticismul față de terapia online a venit din partea terapeuților cu mai multă experiență clinică și tot ei au avut tendința să creadă că utilizarea telepracticii depinde de caracteristicile clienților, atât în privința patologiei cât și a caracteristicilor comportamentale și cognitive. Unele tulburări precum dificultățile de lexie și fluență au fost considerate potrivite pentru terapia online, iar tulburarea deglutiției și dizabilitatea auditivă au fost considerate inadecvate pentru mediul online.

Completarea cu informații privind apelul la tehnologiile online, înțelegerea și dimensiunea practicii online, dar și documentarea comunicării în spațiul virtual în diverse arealuri geografice permite obținerea unui profil relevant în configurarea viitoare a serviciilor educaționale și terapeutice online

Contextul pandemic atrage după sine, pe lângă schimbările din abordarea demersului terapeutic prin utilizarea pe scară largă a terapiei online, și multe schimbări la nivelul resurselor utilizate. Astfel că, pe lângă că au apărut o serie de posibilități virtuale de creare de noi resurse, precum și noi direcții de utilizare a resurselor material preexistente. Talaș (2015) propune analizarea fiecărui caz în parte, pentru a identifica atât beneficiile cât și dificultățile care pot să apară atunci când se recomandă terapia online.

Varietatea și bogăția materialelor logopedice este de subliniat în acest moment, când, forțați de împrejurări mai puțin favorabile, terapeuții limbajului au fost nevoiți să creeze materiale prin care să găsească soluții în vederea continuării demersului terapeutic, absolut necesar beneficiarilor. Bodea Hațegan C și Talaș D. (2020) propun un set de resurse online care pot fi utilizate atât de către terapuți cât și de către carele didactice în activitatea pe care o desfășoară online. 


\section{Obiective}

$\mathrm{Cu}$ ocazia webinarului organizat pentru a marca Ziua Internațională a Terapiei Limbajului, webinar intitulat Telepractica și tehnologiile digitale în terapia tulburărilor de limbaj și de vorbire s-a derulat un studiu de colectare de date cu privire la resursele utilizate de terapeuți.

Obiectivele studiului au fost:

1. identificarea resurselor cele mai frecvent utilizate de terapeuții limbajului în contextul actual pandemic,

2. implementarea aplicației Padlet, ca instrument ce permite colectarea integrată a răspunsurilor la nivelul focusgrupului.

3. identificarea ariilor din domeniul terapiei limbajului care au nevoie de noi resurse și materiale.

\section{Participanții la studiu}

Participanții la studiu au fost în număr de $150 \quad(\mathrm{~N}=150)$, toți participanții sunt membri ai Asociației Specialiștilor în Terapia Tulburărilor de Limbaj din România - ASTTLR și au preocupări în sfera terapiei limbajului, atât în mediul privat, cât și cel de stat.

\section{Instrumente}

Instrumente utilizate în colectarea datelor și procedura de lucru

Padlet - este o platformă care permite utilizatorilor care au acces la linkul creat de un utilizator să scrie, să adauge un hiperlink, o fotografie, sau un document. Toate persoanele care accesează acest link văd în timp real tot ce se scrie sau se postează. (https://padlet.com)
Platforma ZOOM cu activarea opțiunii "breakout rooms" a permis crearea grupelor de lucru și realizarea focus grupului..

Focus grupul este o modalitate de studiu derulată la nivelul unui grup (în cazul de față un grup format din specialiști în terapia tulburărilor de limbaj) prin care se vizează identificarea unor aspecte particulare legate de o problematică centrală (problematica sstudiată este cea resurselor utilizate în mod recurent, în zilele noastre în terapia limbajului) (Krueger R.A., Casey M.A, 2005).

S-a optat pentru utilizarea focusgrupului pentru că se consideră că avantajul major al grupului de specialiști, care împreună aduc în prim plan aspecte nevralgice ale muncii zilnice pe care o derulează și care împreună pot găsi soluții pertinente, este spre deosebire de a interviului, că soluțiiile identificate sunt născute din interacțiunea membrilor grupului.

Deoarece un focus-grup nu poate fi realizat cu un număr mare de participanți, specialiștii în terapia limbajului participanți la studiu au fost împărțiți, în mod aleatoriu, în mai multe grupuri, 25 echipe a câte 6 membri în fiecare echipă. Fiecare grup de lucru trebuie să insereze în Padlet resursele utilizate în demersul terapeutic. Timpul de lucru a fost de 20 minute.

\section{Rezultate obținute}

Datele obținute sunt contabilizate la nivelul link-ului

https://padlet.com/cursuriasttlr/n804dx kdo6y 4 sn 49 


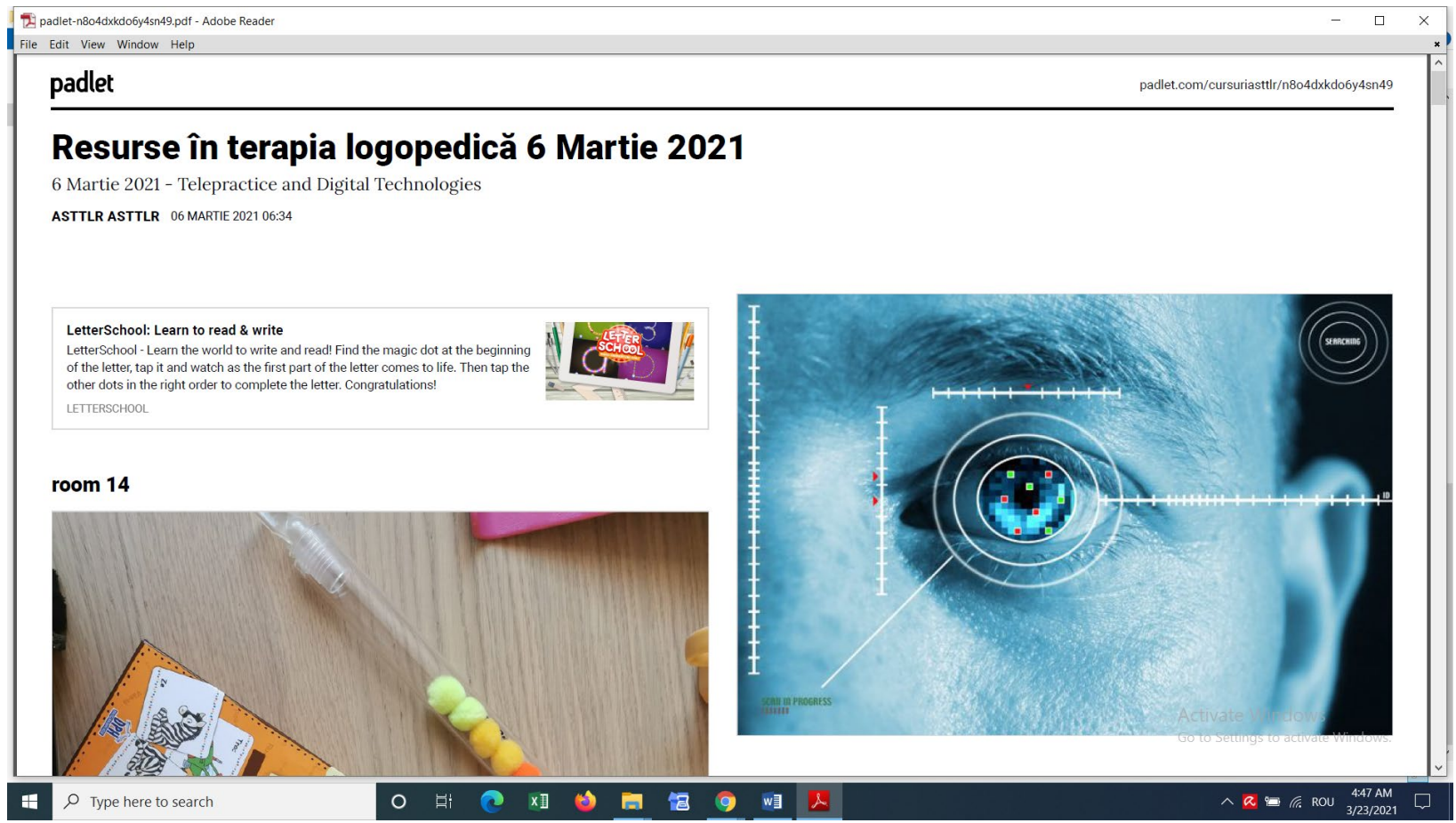

Fig 1. Selecție din rezultatele obținute

\section{Rezultate obținute}

Resursele utilizate în terapia logopedică, descrise și menționate în Padlet de participanții la studiu pot fi grupate în 3 categorii:

1. resurse materiale, clasice care presupun manipulare și care trebuie utilizate de copil sau părinte, ele pot fi utilizate mai concret în contextul terapiei față în față, în online putând fi transpuse doar cu ajutorul părintelui.

Tabel 2. Tipuri de resurse utilizate în terapia logopedică actuală

\begin{tabular}{ll}
\hline \hline Resursele utilizate & Unități menționate \\
\hline Resurse materiale (RM) & 61 \\
\hline $\begin{array}{l}\text { Resurse materiale care pot fi transpuse și în } \\
\text { mediul online (RMV) }\end{array}$ & 17 \\
\hline Resurse virtuale (RV) & 106 \\
\hline
\end{tabular}

Se poate constata faptul că datele polarizează înspre utilizarea resurselor virtuale, digitale, numărul acestora fiind
2. resurse materiale clasice care pot fi transpuse/transferate și în mediul online,

3. resurse virtuale (aplicații, platforme digitale, softuri etc.).

În tabelul de mai jos ilustrăm și sub aspect cantitativ modul în care cele trei tipuri de resurse sunt menționate a fi utilizate în demersul terapeutuc actual, de participanții la studiu: aproape dublu față de cel al resurselor materiale. 


\section{Discuții}

În continuare se analizează fiecare categorie de resurse delimitată de participanții la studiu și se ilustrează cu exemple colectate.

\section{Resurse materiale}

Resursele materiale existente pot $\mathrm{fi}$ utilizate în variante terapiei online mai dificil. Ele au fost create pentru a fi utilizată în demersul terapeutic față în față. Utilizarea acestor resurse în mediul online, terapeutul având rolul de ghidare și îndrumare, se poate realiza doar dacă se solicită părinților copiilor/aparținătorilor persoanelor aflate în demersul terapeutic să achiziționeze aceste materiale. S-ar putea spune că această situație ar atrage costuri mai mari pentru părinte. În fapt, chiar și în contextul terapiei față-în-față anumite produse erau achiziționate de către părinte tocmai din motive de siguranță și igienă, producătorii lor recomandând utilizarea individuală.

Dintre aceste produse menționate de terapeuții limbajului participanți la studiu, care se utilizează frecvent în demersul terapeutic logopedic și pe care părintele le poate achiziționa și utiliza sub ghidarea online a terapeutului aducem în prim plan:

\section{Flow-Ball}

Acesta este un dispozitiv neelectronic, ușor de manipulate și utilizat, dar care are $\mathrm{o}$ valoare crescută în demersul therapeutic pentru a facilita prelungirea expirului, cu scopul pregătirii unei respirații verbale funcționale. De asemenea, Flow-Ball se poate utiliza și pentru creșterea volumului respirator, a tonifierii musculare implicate în actul respirator, dar și pentru a relaxa și tensiona musculatura implicată în actul fono-articulator.

Lã, Wistbacka, Andrade, Granqvist (2017) au subliniat valoare acestui tip de instrumente în educarea respirației cu scopul modelării vocii, subliniind că biofeedback-ul vizual care este asigurat de urmărirea mingii ce trebui să fie propulsată în aer, alături de antrenarea respirației prin tub (Smith, Titze, 2017), conduce la îmbunătățirea clară a capacității de expir, iar abilitatea de prelungire a expirului este absolut necesară în actul fonator.

Flow-Ball se poate utiliza de la vârste foarte mici, chiar de la vârsta de 1 an și are valoare terapeutică și la adulți.

\section{Breath-Builder}

Acesta este un dispozitiv neelectronic, ușor de utilizat, care poate fi utilizat foarte eficient în vederea creșterii volumului respirator și antrenării capacității respiratorii, a tensionării musculare diafragmatice, a diferențierii inspirului de expir și a respirației orale de cea nazale .

Breath-Builder nu poate fi utilizat în activitățile cu copiii antepreșcolari. Valoarea lui terapeutucă este mai crescută în activitățile pentru școlari, adolescenți și adulți. Este utilizat și studiat pe scară largă și în contextul modelării respirației la cântăreți, unde beneficiile acestuia sunt studiate (Mazon, 2009).

\section{Solo-Phone Whisper}

Este un dispozitiv neelectronic, ușor de pus în practică chiar și de către părinte și copil. Acesta constă într-o cordeluță care 
se plasează pe cutia craniană și se fixează printr-un punct la nivelul urechii. De asemenea, dispozitivul are și o parte care ajută în captarea sunetelor emise. Practic, acest dispozitiv valorifică conducția osoasă, potențând autoaudiția și facilitează: creșterea abilităților perceptiv-auditive, dezvoltarea abilităților atenționale, creșterea abilităților de diferențiere și discriminare auditivă. Dispozitivul poate fi utilizat cu succes chiar și terapia copiilor cu dizabilități sau tulburări (ADHD, TSA, dizabilitate intelectuală sau tulburări de dezvoltare). În contextul terapiei limbajului acest dispozitv are o valoare crescută în antrenarea abilităților de procesare auditivă, în etapa logopedică de formare a preachizițiilor limbajului.

\section{$\underline{\text { Kit-ul TALK TOOLS }}$}

Acesta este constituit dintr-un bogat set de instrumente variate, obiecte, jucării menite să fie utilizate în vederea antrenării grupelor motorii oro-faciale. Kit-ul conține: Horn Kit (instrumente pentru antrenarea respirației), Straw Kit (paie de diferite forme și mărimi pentru antrenarea respirației, a musculaturii labiale și a vocii), Spinner și Toothies (un instrumentar care permite evaluarea sensibilității și, în același timp, antrenarea oro-motorie) și 2 seturi de instrumente pentru antrenarea maxilarelor, a abilităților masticatorii (Jaw Grading Bite Blocks). Kit-ul Talk Tools vine să deschidă perspectiva de abordare oro-motorie într-o altă paradigmă (Bahr, Rosenfeld-Johnson, 2010), cea a poziționării corecte a subcomponentelor aparatului fonoarticulator, nu a sublinierii importanței antrenării motorii a grupelor musculare, în contextul în care cercetările anterioare nu au putut aduce dovezi științifice în a susține antrenarea motorie oro-facială ca fiind valoroasă în corectarea tulburărilor de pronunție (Lof, Watson, 2008; Lass, Pannbacker, 20o8; McCauley, Strand, Lof, Schooling \& Frymark, 2009).

Varietatea instrumentelor, posibilitatea ca acestea să fie improvizate în casă de părinte, simplitatea unora dintre acestea subliniază încă o dată faptul că este important să cooptăm părintele, aparținătorii în acest demers al terapiei logopedice.

Cele patru instrumente materiale prezentate pot fi utilizate și în contextul reabilitării persoanei care a trecut printrun episod sever de infecție cu virusul pandemic SARS-CoV-2 (Ali Ismail, 2020). Ele pot fi utilizate fie demonstrându-i părintelui, aparținătorului sau chiar persoanei aflată în terapie cum se utilizează pe parcursul întâlnirilor online. De asemenea, pot fi utilizate prin modelare video și se poate constata că pe site-urile care comercializează aceste produse sunt o mulțime de înregistrări video cu exemplificări ale modului de utilizare a instrumentelor și explicațiile necesare.

\section{Resurse materiale faptice}

Resursele materiale faptice, concrete ce se foloseau în paradigma tradițională clasică, față-în-față pot fi transpuse în varianta terapeutică online fie prin:

- Scanare- dacă ne referim la utilizarea unor cărți cu fișe,

- Partajarea unor fișe tehnoredactate care în varianta de terapie față în față se lucrau după ce erau listate, iar online se lucrează prin împărtășirea 
lor prin intermediul platformelor online și completarea lor fie de către terapeut, fie de beneficiar, cu ajutorul funcției "Control la distanță".

- Arătarea lor prin intermediul camerei web - dacă e vorba de jucării, jocuri, obiecte concrete, machete, cartonașe etc.

-Utilizare/manipularea de către terapeut a unor materiale care nu pot fi angrenate în procesul terapeutic transpus online altfel, de exemplu puzzle-urile, cuburi, biluțe și capse utilizate în jocurile de tip mozaic.

Dintre aceste resurse participanții la studiu menționează: cărțile cu fișe logopedice, jocurile create pentru domeniul logopedic sub cupola "Jucării Vorbărețe", cartonașele de tip Montessori, cărțile de povești, puzzleurile, cartonașele ABCDELA- silabe, cuvinte monisilabice, cartonașele din jocul MIADE, cartonașele de la editura GAMA.

Este de menționat că deși numărul acestor menționări este cu mult mai mic, decât în cazul resurselor materiale sau a celor virtuale $(\mathrm{N}=17)$, acest aspect se datorează faptului că acestea sunt delimitate prin prisma categoriilor, nu prin primsa unor unități specifice, (de exemplu: categoria cărți cu fișe logopedice nu se detaliază cu exemple concrete).

\section{Resursele virtuale}

Resursele virtual elaborate, resursele care au fost elaborate online și care pot fi utilizate în demersul terapeutic online fie direct de către părinte sau de terapeut prin utilizarea unor platforme care permit rularea lor în mod interactiv.
Dintre aceste resurse pentru domeniul terapeutic logopedic din țară specific create și utilizate de respondenții la studiu sunt:

a.Site-ul https://cubulet.ro/- este un site care facilitează generarea de fișe de lucru pentru antrenarea fluenței în citire, dar și în calcul matematic. De asemenea, siteul conține și jocul Bingo Educațional. Acest site a fost gândit ca un generator de resurse educaționale deschise online.

b. Wordwall este o platformă foarte utilizată în vederea creării de resurse terapeutice, este la îndemâna oricărui terapeut care își deschide un cont sau chiar și fără a avea cont configurat. Platforma pune la dispoziția specialiștilor o serie de resurse deja create, dar oferă și posibilitatea de a-ți elabora și propriile resurse.

c. Liveworkheets este o platformă bogată în resurse create virtual și care pot fi utilizate în domeniul terapeutic logopedic, mai ales resurse care se adresează școlarilor și prin intermediul lor sunt abordate aspecte legate de formarea abilităților de scris-citit și calcul matematic.

d. Story Board That este un site care permite elaborarea online a unor scurte povestioare. Este un instrument care facilitează în special antrenarea abilităților lingvistice propoziționale și discursive, precum și formarea abilităților narative și a deprinderilor social-contextuale.

e. Word Eminus este o platformă educațională care permite evaluarea preachizițiilor limbajului, cu scopul configurării unui program de prevenție, încă din perioada ultimului an de 
grădiniță, a tulburărilor de învățare care pot surveni. Este creat respectând specificul limbii române prin intermediul proiectul TALK (2017-2019) (Bodea Hațegan, 2019).

Ultimul obiectiv al cercetării a fost identificarea subdomeniului logopedic în care au fost menționate resursele cele mai puține pentru a avea în vedere acest aspect în demersurile viitoare. În baza răspunsurilor oferite, subdomeniul cel mai puțin bogat în resurse a fost cel morfologic, aici au fost indicate doar 2 resurse, ceea ce deschide direcții pentru cercetări viitoare.

\section{Concluzii}

Acest focus-grup organizat pentru a surprinde specificul utilizării resurselor în domeniul terapiei logopedice a condus la delimitarea a trei categorii de resurse terapeutice: resursele materiale, resursele materiale care pot fi transpuse în mediul virtual și resursele virtuale. Răspunsurile terapeuților au polarizat spre detalierea și enumerarea resurselor virtuale, ceea ce este în concordanță cu vremurile pandemice pe care le traversăm și care, se pare că nu se vor încheia prea curând. Terapeuții limbajului sunt clar preocupați de identificarea și împărtășirea de resurse virtuale și au lăsat în plan secund resursele materiale clasice, iar transpunerea resurselor clasice în mediul online, se pare că este înlocuită cu tendința de a identifica și crea resurse direct cu scopul de a fi utilizate virtual.

Ca direcție viitoare de studiu și cercetare $\mathrm{s}$-a desprins subdomeniul morfologic al limbajului care are nevoie de mai multă atenție sub aspectul resurselor ce pot fi utilizate, atât la nivel receptiv, cât și expresiv, astfel asumarea nevoii de a crea resurse virtuale pe acest subdomeniu al limbajului se desprinde specific.

\section{Bibliografie:}

Ali Ismail, A. (2020). Online exercise rehabilitation to stable COPD patients during the second COVID wave: are physiotherapists able to help?. Advances in Rehabilitation, 34(4), 48-49. https://doi.org/10.5114/areh.2020.1015 92

Alqudah, S., Zaitoun, M., Alqudah, O., Alqudah, S., \& Alqudah, Z. (2021). Challenges facing users of hearing aids during the COVID-19 pandemic. International Journal of Audiology, 17 .

https://doi.org/10.1080/14992027.2021 .1872806

Bahr, D., Rosenfeld-Johnson,S. (2010). Treatment of children with Speech Oral Placement Disorders (OPDs): A Paradigm Emerges. Communication Disorders Quarterly, XX(X) 1-8.

Becker, D. R., \& Gillespie, A. I. (2021). In the Zoom Where It Happened: Telepractice and the Voice Clinic in 2020. Seminars in Speech and Language, $\quad 42(01), \quad 064-072$. https://doi.org/10.1055/s-00401722750

Bodea Hațegan, C. (2019). TALK Language and literacy curriculum for pre-schoolers and school-age children: a programme to improve inclusion, scholastic achievement and social well-being (TALKCHIL), în Revista Română de Terapia Tulburărilor de Limbaj și 
Comunicare-RRTTLC, V/2019, Nr. 1, ASTTLR, Cluj-Napoca, p.3-7, ISSN: 2457-9262 (indexed in Erih Plus, CEEOL, DOAJ ). DOI: 10.26744/rrttlc.2019.5.1.02

Bodea Hațegan, C., Talaș D. (2020) Ghid practic de organizare a activităților online. Presa Universitară Clujeană. http://www.editura.ubbcluj.ro/www/ ro/ebooks/domains.php?id=16

Boisvert, M., Lang, R., Andrianopoulos, M., \& Boscardin, M. L. (2010). Telepractice in the assessment and treatment of individuals with autism spectrum disorders: A systematic review. In Developmental Neurorehabilitation (Vol. 13, Issue 6, pp. 423-432). https://doi.org/10.3109/17518423.2010. 499889

Cohn, E. R. (2012). Tele-Ethics in Telepractice for Communication Disorders. Perspectives on Telepractice, 2(1), 3-15. https://doi.org/10.1044/tele2.1.3

Edwards, M., Stredler-Brown, A., \& Houston, K. T. (2012). Expanding Use of Telepractice in Speech-Language Pathology and Audiology.: EBSCOhost. The Volta Review, 112(3), 227-242.

http://web.a.ebscohost.com/ehost/p dfviewer/pdfviewer?vid=28\&sid=3fa2 3712-8835-4a49-9dade64be7f26113\%40sessionmgr40o1\&hid $=4114$

Europe Internet Use and Population Statistics. (2020). https://www.internetworldstats.com/ stats4.htm\#europe
Finch, E., Lethlean, J., Rose, T., Fleming, J., Theodoros, D., Cameron, A., Coleman, A., Copland, D., \& McPhail, S. M. (2020). Conversations between people with aphasia and speech pathology students via telepractice: A Phase II feasibility study. International Journal of Language and Communication Disorders, 55(1), 4358. https://doi.org/10.1111/1460$\underline{6984.12501}$

Fong, R., Tsai, C. F., \& Yiu, O. Y. (2021). The Implementation of Telepractice in Speech Language Pathology in Hong Kong during the COVID-19 Pandemic. Telemedicine and EHealth, 27(1), 30-38. https://doi.org/10.1089/tmj.2020.0223

Hall, N., Boisvert, M., \& Steele, R. (2013). Telepractice in the Assessment and Treatment of Individuals with Aphasia: A Systematic Review. International Journal of Telerehabilitation, 5(1). https://doi.org/10.5195/ijt.2013.6119

Harrison, D. (2011). Speech Language Clinicians Connect with Telepractice. The Journal. https://thejournal.com/articles/2011/ 02/02/speech-language-cliniciansconnect-with-telepractice.aspx

Kim, N. Y., Ha, J. W., Park, K. S., Lee, G. J., Park, S. N., \& Bae, Y. S. (2020). Perception of Korean SpeechLanguage Pathologists on Telepractice Service. Communication Sciences and Disorders, 25(4), 987997.

https://doi.org/10.12963/CSD.20776

Kraljević, J. K., Matić, A., \& Dokoza, K. P. (2020). Telepractice as a reaction to 
the COVID-19 crisis: Insights from croatian slp settings. International Journal of Telerehabilitation, 12(2), 93-104.

https://doi.org/10.5195/ijt.2020.6325

Krueger R.A., Casey M.A, (2005). Metoda focus-grup. Ghid practic pentru cercetarea aplicată, trad. Rom. Cristina Popa, Polirom, Iaşi (ediţie originală 2000, Sage Publications).

Lã, F., Wistbacka, G., Andrade, P. A., \& Granqvist, S. (2017). Real-Time Visual Feedback of Airflow in Voice Training: Aerodynamic Properties of Two Flow Ball Devices. Journal of Voice: official journal of the Voice Foundation, 31(3), $\quad$ 390.e1-390.e8. https://doi.org/10.1016/j.jvoice.2016.0 9.024

Lam, J. H. Y., Lee, S. M. K., \& Tong, X. (2021). Parents' and students' perceptions of telepractice services for speech-language therapy during the COVID-19 pandemic: Survey study. JMIR Pediatrics and Parenting, 4(1). https://doi.org/10.2196/2567 5

Lass, N. J. \& Pannbacker, M. (2008). The application of evidence-based practice to nonspeech oral motor treatments. Language, Speech, and Hearing Services in Schools, 39, 408421.

Lof, G. L. \& Watson, M. M. (2008). A nationwide survey of nonspeech oral motor exercise use. Language, Speech, and Hearing Services in Schools, 39 392-407.

Mazon, W. E. (2009). The effect of the breath builder ${ }^{\mathrm{TM}}$ on various lung functions and musical performance abilities of clarinet players, Faculty of the SCHOOL OF MUSIC; university of Arizona, retrieved in 20.02.2021 from

http://www.windsongpress.com/jaco bs/written/Mazon\%20-

\%20THE\%20EFFECT\%20OF\%20THE \%2oBREATH\%2oBUILDER\%E2\%84 \%A2\%20ON\%20VARIOUS\%20LUNG \%20FUNCTIONS.pdf

McCauley R.J., Strand E., Lof, G.L., Schooling T. \& Frymark, T. (2009). Evidence-Based Systematic Review: Effects of Nonspeech Oral Motor Exercises on Speech, American Journal of Speech-Language Pathology, 18, 343-360.

Narzisi, A. (2020). Phase 2 and Later of COVID-19 Lockdown: Is it Possible to Perform Remote Diagnosis and Intervention for Autism Spectrum Disorder? An Online-Mediated Approach. Journal of Clinical Medicine, $\quad 9(6), \quad 1850$. https://doi.org/10.3390/jcm9061850

Pamplona, M. del C., \& Ysunza, P. A. (2020). Speech pathology telepractice for children with cleft palate in the times of COVID-19 pandemic. International Journal of Pediatric Otorhinolaryngology, 138, 110318. https://doi.org/10.1016/j.ijporl.2020.11 $\underline{0318}$

Parsons, D., Cordier, R., Vaz, S., \& Lee, H. C. (2017). Parent-mediated intervention training delivered remotely for children with autism spectrum disorder living outside of urban areas: Systematic review. In Journal of Medical Internet Research (Vol. 19, Issue 8). JMIR Publications Inc. https://doi.org/10.2196/jmir.6651 
Polovoy, C. (2008). Telepractice in schools helps address personnel shortages. In ASHA Leader (Vol. 13, Issue 9).

Samadi, S. A., Bakhshalizadeh-Moradi, S., Khandani, F., Foladgar, M., Poursaid-Mohammad, M., \& McConkey, R. (2020). Using hybrid telepractice for supporting parents of children with asd during the COVID19 lockdown: A feasibility study in Iran. Brain Sciences, 10(11), 1-14. https://doi.org/10.3390/brainsciolio8 92

Smith, S. L., \& Titze, I. R. (2017). Characterization of Flow-resistant Tubes Used for Semi-occluded Vocal Tract Voice Training and Therapy. Journal of Voice : official journal of the Voice Foundation, 31(1), 113.e1-113.e8.

https://doi.org/10.1016/j.jvoice.2016.0 4.001

Talaș D. (2015).Terapia tulburărilor de limbaj derulată online. în Revista Română de Terapia Tulburărilor de Limbaj și Comunicare-RRTTLC, I/2015, Nr. 1, ASTTLR, Cluj-Napoca, p.34-40, ISSN: 2457-9262 . DOI: 10.26744/rrttlc.2015.1.1.05

Theodoros, D. (2011). Telepractice in Speech-Language Pathology: The Evidence, the Challenges, and the Future. Perspectives on Telepractice. https://doi.org/10.1044/tele1.1.10

Todd Houston, K., Stredler-Brown, A., \& Alverson, D. C. (2012). More than 150 years in the making: The evolution of telepractice for hearing, speech, and language services. In Volta Review. https://doi.org/10.17955/tvr.112.3.m.70 9
Trifu, R. N., Münch, H., Kleer, F., \& Mészáros, É. (2018). Telepractice in SLT. Results from an european survey. Book of Abstract. 1oth CPLOL European Congress of Speech and Language Therapy, 226.

WIS. (2020). World Internet Users Statistics and 2020 World Population Stats.

https://www.internetworldstats.com/ stats.htm

https://cubulet.ro/

https://www.liveworksheets.com/

https://www.storyboardthat.com/

https://words.eminus.pl/

https://wordwall.net/

http://www.editura.ubbcluj.ro/bd/eboo ks/pdf/2829.pdf

https://www.originalbreathbuilder.com/ https://talktools.com/

https://talktools.com/products/introkit?variant $=28452056905$

${ }^{1}$ Conf. univ. dr., Departamentul de Psihopedagogie Specială, Facultatea de Psihologie şi Ştiinţe ale Educaţiei, Universitatea Babeş-Bolyai, Cluj-Napoca; E-mail:carolina.bodea.hategan@gmail.com

${ }^{2}$.Lector asociat dr. Departamentul de Psihopedagogie Specială, Facultatea de Psihologie şi Ştiinţe ale Educaţiei, Universitatea Babeș-Bolyai, Cluj-Napoca; E-mail: tdorina@yahoo.com

3.Asistent universitar dr. Disciplina de Psihologie Medicală, Universitatea de Medicină și Farmacie „Iuliu Hațieganu” Cluj-Napoca.

Email: raluca.trifu@umfcluj.ro 